\title{
Study of the additive effect of timolol and epinephrine in lowering intraocular pressure
}

\author{
JOHN V. THOMAS AND DAVID L. EPSTEIN \\ From the Glaucoma Clinical Research Center, Massachusetts Eye and Ear Infirmary, Harvard Medical \\ School, Boston, Massachusetts, USA
}

SUMMARY A randomised, double-masked clinical study was conducted in patients with primary open-angle glaucoma to determine if timolol and epinephrine have an additive effect in lowering intraocular pressure. Sixteen patients were randomly assigned to one of 2 treatment sequences (timolol alone, supplemented after 2 weeks with epinephrine, and vice versa). An initial additive effect in lowering intraocular pressure was found in both sequences. However, after several weeks of combined therapy complete loss of additive effect was found. Patients who were treated first with epinephrine for 2 weeks and then supplemented with timolol had significantly lower intraocular pressures for at least 2 weeks than patients in the reverse treatment sequence. Epinephrine treatment alone caused a significant increase in facility of outflow, but this effect did not occur with simultaneous timolol treatment. The results are discussed in terms of possible fundamental beta and alpha adrenergic influences on aqueous dynamics and their potential clinical relevance.

Timolol is a beta adrenergic blocking agent which competes with catecholamines for adrenergic beta receptor sites. It has been shown to lower intraocular pressure in normal and glaucomatous animal eyes, ${ }^{1-3}$ in normal volunteers, ${ }^{4}$ and in patients with glaucoma. ${ }^{5-10}$ The reduction in intraocular pressure produced by timolol is probably due to specific blockade of beta adrenergic receptors. ${ }^{11}$ It is obvious that if timolol were found to be additive to other intraocular pressure-reducing drugs it would represent an important advance in the treatment of glaucoma.

A few studies ${ }^{12-14}$ have indicated that timolol has a statistically significant additive effect when used in patients receiving maximum-tolerated antiglaucoma therapy. However, it has also been reported that this additive effect in lowering intraocular pressure is not clinically significant. ${ }^{15}$ It is important to note that the results of the above studies do not imply that timolol has an additive effect with each of the several drugs that constitutes maximal medical therapy.

Timolol acts as an antagonist at adrenergic beta receptor sites, while epinephrine is an agonist at adrenergic alpha and beta receptor sites. It is therefore of both practical and theoretical significance to determine if these 2 drugs, when used

Correspondence to John V. Thomas MD. 100 Charles River Plaza. Cambridge Street. Boston. Mass. 02114. USA together, have an additive effect in lowering intraocular pressure.

Radius et al. ${ }^{16}$ have reported in a single-drop study that epinephrine given to rabbits pretreated with timolol has a small additive effect in lowering intraocular pressure which lasts for approximately 9 hours. However, albuterol (a beta agonist) when used in animals pretreated with timolol did not produce any further lowering of intraocular pressure.

A few investigators ${ }^{1718}$ have noted their clinical impression that there is an enhanced reduction of intraocular pressure when epinephrine is used in patients already on timolol, and Nielson ${ }^{19}$ has recorded an additional reduction of intraocular pressure by epinephrine in eyes treated with timolol. However, Boger et al. ${ }^{7}$ did not find any such additive effect.

We decided therefore to conduct a randomised, double-masked clinical study to determine with greater certainty whether timolol and epinephrine have an additive effect in lowering intraocular pressure in patients with primary open-angle glaucoma.

\section{Patients and methods}

The criteria for inclusion of patients and for their continuance in this study were the presence of optic nerves healthy enough to be safe without treatment 
for a month, applanation tensions greater than or equal to $23 \mathrm{mmHg}$ without treatment, open angles by gonioscopy, and stable visual fields. Patients were excluded if they had a history of recent ocular infection, cataract extraction and/or other surgical procedures, severe ocular trauma within 3 months, current contact lens usage or use within 3 weeks, corneal foreign body within 1 month, dendritic keratitis or active corneal ulcer within 3 months, corneal abnormalities preventing reliable applanation tonometry, allergy to epinephrine, uveitis, angle closure, and bronchial asthma or chronic obstructive pulmonary disease. Further, patients receiving propranolol or other systemic $\beta$-adrenergic blocking drugs, pregnant or nursing women, patients with heart rates of less than 56 beats per minute after 4 minutes of rest, and children were excluded.

A total of 31 eyes of 16 patients were selected for the study. The patients, 9 men and 7 women, ranged in age from 31 to 78 years with an average age of 62 years. Fourteen patients were white and 2 were black. All subjects were informed precisely of the nature of the study before they gave their consent.

The treatment protocol is presented in Fig. 1. After 2 weeks without any medication the patients returned for a complete baseline examination including Goldmann applanation tension measurements every hour for 4 consecutive hours, followed by tonography.

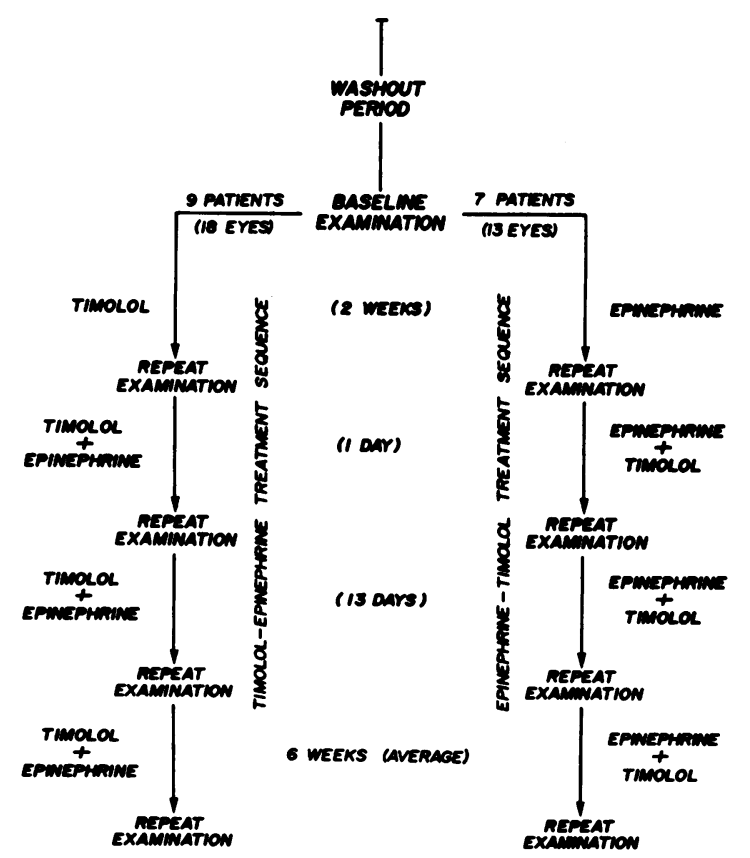

Fig. 1 Flow diagram of treatment protocol.
The patients were then assigned to 1 of 2 treatment groups according to a table of random numbers. Eighteen eyes in 9 patients were treated with timolol maleate $1 / 2 \%$ (Timoptic) twice a day for 2 weeks. Thirteen eyes in 7 patients were treated with epinephrine borate $1 \%$ (Eppy) twice a day for 2 weeks. Coded, identical-appearing bottles were used to dispense both medications. Physicians examining the patients, technicians performing tonography, and the patients themselves were unaware of the drugs being used.

At the end of 2 weeks all patients returned for repeat 4-hourly intraocular pressure measurements and tonography. The regular morning dose of the medication was administered by the nurse prior to the measurements of intraocular pressure.

Then epinephrine was added to the regimen of patients who had been treated with timolol alone, and timolol was added to the regimen of patients who had been treated with epinephrine alone. The medications were administered 1 minute apart by the patients at home and by the nurse on the morning of the clinic visit. All patients returned after 1 day and after 2 weeks of combined therapy with timolol and epinephrine. Measurements of intraocular pressure and tonography were similarly repeated at both visits. Combined therapy was then continued.

Pressure measurements were repeated at the last visit, which took place at periods of time varying from 4 to 15 weeks (average 6 weeks) after the previous visit. We used a straight-line extrapolation to calculate intraocular pressure data points 10 weeks after the start of the experiment so that we could compare results from all patients.

Measurements of intraocular pressure were performed at approximately the same time of day on each visit in order to minimise the influence of diurnal variation. The changes in intraocular pressure were expressed in terms of mean percentage reduction in outflow pressure consistently using $10 \mathrm{mmHg}$ as episcleral venous pressure, as determined previously for similar patients with primary open-angle glaucoma in our clinic. ${ }^{20}$

The calculations reported in this paper for intraocular pressure are based on the mean of 5 applanation measurements per subject per test day. We determined the significance of differences between the 2 groups with a standard $t$-test and differences within treatment series with a $t$-test for paired samples. To ensure independence the tests were done on left eyes (i.e., left and right eyes were not pooled). Tests of both absolute and relative (percentage change) differences were consistent. As a further check we also computed $t$ values for individual applanation measurements (e.g., first measurement on day $x$ with first measurement on day $y$, second with 


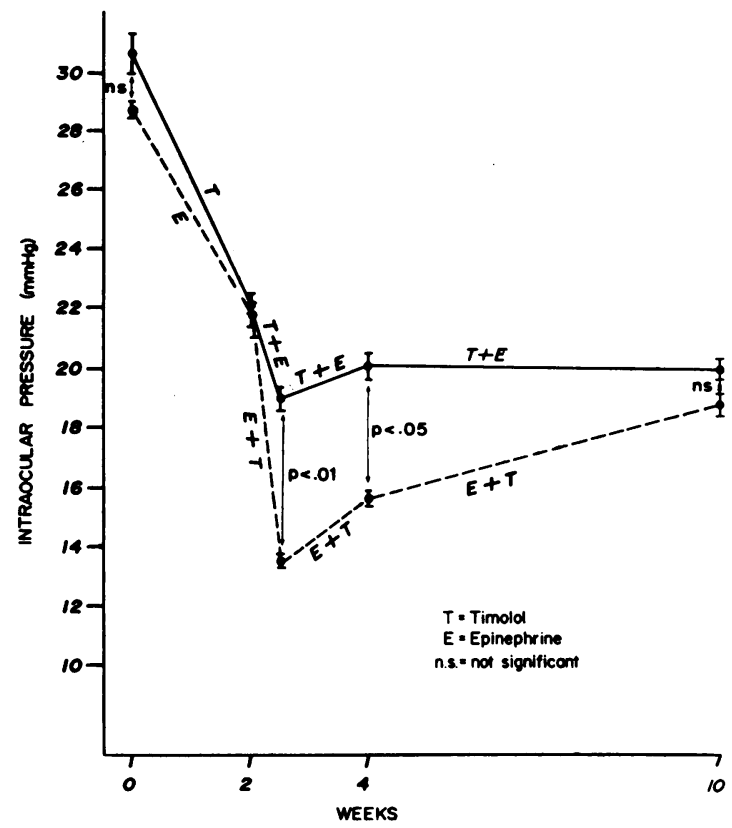

Fig. 2 Intraocular pressure measurements in the 2 treatiment sequences. ( $T=$ timolol; $E=$ epinephrine; $T+E=$ timolol supplemented with epinephrine; $E+T=$ epinephrine supplemented with timolol).

second, etc.), and repeated the entire series of calculations on right-eye measurements. Tonography data are based on a single measurement per eye per visit. Calculations were done on left and right eyes separately and were consistent. Pressure measurement and tonography data from left eyes are presented in the tables.

\section{Results}

After treatment with timolol alone for 2 weeks a significant reduction of outflow pressure was found. (Fig. 2, Table 1). One day after epinephrine was added to timolol there was a significant additive reduction in outflow pressure (Table 1). This additive effect of epinephrine was still present, but diminished, after 2 weeks of combined therapy (Table 1). However, after an average of 8 weeks of combined therapy there was no significant additive reduction in outflow attributable to epinephrine (Table 1).

In patients treated with epinephrine alone for 2 weeks there occurred a significant reduction in outflow pressure (Fig. 2, Table 2). One day after timolol was added to the epinephrine regimen there was a significant additive reduction in outflow pressure (Table 2). Two weeks after combined therapy in this sequence an additive reduction in outflow pressure attributable to timolol was still present, but the net additive effect was significantly less (Table 2). After an average of 8 weeks of combined therapy no significant additive effect was attributable to timolol (Table 2).

The data expressed in terms of absolute $\mathrm{mmHg}$ showed the same levels of statistical significance.

A significant difference in the intraocular pressure reduction was found between the 2 treatment sequences (Fig. 2). Pretreatment pressures of the 2 groups were not significantly different. The drop in intraocular pressure when timolol was added to

Table 1 Mean percentage reduction of outflow pressure in timolol-epinephrine treatment sequence

\begin{tabular}{|c|c|c|}
\hline & $\begin{array}{l}\text { Mean \% reduction of } \\
\text { outflow pressure }\end{array}$ & Significance \\
\hline $\begin{array}{l}\text { After timolol for } 2 \\
\text { weeks-compared with } \\
\text { pretherapy level }\end{array}$ & $-34 \cdot 5 \% \pm 6 \cdot 4$ & $\mathrm{p}<0.001$ \\
\hline $\begin{array}{l}\text { After } 2 \text { weeks of } \\
\text { timolol and } 1 \text { day of } \\
\text { timolol and epinephrine } \\
\text {-compared with } \\
\text { timolol after } 2 \text { weeks }\end{array}$ & $-21 \cdot 1 \% \pm 5 \cdot 4$ & $\mathrm{p}<0.01$ \\
\hline $\begin{array}{l}\text { After } 2 \text { weeks of } \\
\text { timolol and } 2 \text { weeks of } \\
\text { timolol and epinephrine } \\
\text {-compared with } \\
\text { timolol after } 2 \text { weeks }\end{array}$ & $-14 \cdot 4 \% \pm 4 \cdot 6$ & $p<0.05$ \\
\hline $\begin{array}{l}\text { After } 2 \text { weeks of } \\
\text { timolol and } 8 \text { weeks of } \\
\text { timolol and epinephrine } \\
\text {-compared with } \\
\text { timolol after } 2 \text { weeks }\end{array}$ & $-10 \cdot 2 \% \pm 7 \cdot 9$ & $p>0.1$ \\
\hline
\end{tabular}

Table 2 Mean percentage reduction of outflow pressure in epinephrine-timolol treatment sequence

\begin{tabular}{|c|c|c|}
\hline & $\begin{array}{l}\text { Mean \% reduction of } \\
\text { outflow pressure }\end{array}$ & Significance \\
\hline $\begin{array}{l}\text { After epinephrine for } 2 \\
\text { weeks-compared with } \\
\text { pretherapy level }\end{array}$ & $-37 \cdot 6 \% \pm 8 \cdot 2$ & $\mathrm{p}<0.01$ \\
\hline $\begin{array}{l}\text { After } 2 \text { weeks of } \\
\text { epinephrine and } 1 \text { day } \\
\text { of epinephrine and } \\
\text { timolol-compared with } \\
\text { epinephrine after } 2 \\
\text { weeks }\end{array}$ & $-58 \cdot 7 \% \pm 9 \cdot 4$ & $p<0.001$ \\
\hline $\begin{array}{l}\text { After } 2 \text { weeks of } \\
\text { epinephrine and } 2 \\
\text { weeks of epinephrine } \\
\text { and timolol-compared } \\
\text { with epinephrine after } \\
2 \text { weeks }\end{array}$ & $-36 \cdot 2 \% \pm 12 \cdot 3$ & $\mathrm{p}<0.05$ \\
\hline $\begin{array}{l}\text { After } 2 \text { weeks of } \\
\text { epinephrine and } 8 \\
\text { weeks of epinephrine } \\
\text { and timolol-compared } \\
\text { with epinephrine after } \\
2 \text { weeks }\end{array}$ & $-15 \cdot 5 \% \pm 17 \cdot 1$ & $p>0.2$ \\
\hline
\end{tabular}


epinephrine was significantly greater than when epinephrine was added to timolol both after 1 day $(\mathrm{p}<0.01)$ and after 2 weeks $(\mathrm{p}<0.05)$ of combined therapy. However, after an average of 8 weeks of combined therapy we could find no significant difference in pressure reduction between the 2 treatment sequences.

Tonography measurements revealed that after 2 weeks of treatment with epinephrine alone there was a significant increase in facility of outflow (Table 3 ). One day after timolol was added no significant change in facility of outflow occurred. However, after 2 weeks of combined therapy a significant decrease in outflow facility was observed.

Tonography measurements in the other treatment sequence revealed that after two weeks of treatment with timolol alone there was a significant increase in facility of outflow (Table 4). However, adding

Table 3 Tonography data in epinephrine-timolol treatment sequence

\begin{tabular}{lll}
\hline & $\begin{array}{l}\text { Facility of outflow } \\
(\mu \mathrm{l} / \mathrm{min} / \mathrm{mmHg})\end{array}$ & Change \\
\hline Pretreatment & $0 \cdot 09 \pm 0 \cdot 01$ & $\begin{array}{l}\text { Increase } \\
(\mathrm{p}<0 \cdot 02)\end{array}$ \\
$\begin{array}{l}\text { After } 2 \text { weeks of } \\
\text { epinephrine }\end{array}$ & $0 \cdot 17 \pm 0 \cdot 03$ & $\begin{array}{l}\text { No change } \\
(\mathrm{p}>0 \cdot 2)\end{array}$ \\
$\begin{array}{l}\text { After 2 weeks of } \\
\text { epinephrine and } 1 \text { day } \\
\text { of epinephrine and } \\
\text { timolol }\end{array}$ & $0 \cdot 18 \pm 0 \cdot 02$ & $\begin{array}{l}\text { Decrease } \\
(\mathrm{p}<0 \cdot 001)\end{array}$ \\
$\begin{array}{l}\text { After 2 weeks of } \\
\text { epinephrine and 2 } \\
\text { weeks of epinephrine } \\
\text { and timolol }\end{array}$ & $0 \cdot 13 \pm 0 \cdot 02$ & \\
\hline
\end{tabular}

Table 4 Tonography data in timolol-epinephrine treatment

\begin{tabular}{lll}
\hline & $\begin{array}{l}\text { Facility of outflow } \\
(\mu / / \mathrm{min} / \mathrm{mmHg})\end{array}$ & Change \\
\hline Pretreatment & $0 \cdot 11 \pm 0 \cdot 02$ & $\begin{array}{l}\text { Increase } \\
(\mathrm{p}<0 \cdot 02)\end{array}$ \\
$\begin{array}{l}\text { After 2 weeks of } \\
\text { timolol }\end{array}$ & $0 \cdot 16 \pm 0 \cdot 02$ & $\begin{array}{l}\text { No change } \\
(\mathrm{p}>0 \cdot 09)\end{array}$ \\
$\begin{array}{l}\text { After 2 weeks of } \\
\text { timolol and 1 day of } \\
\text { timolol and } \\
\text { epinephrine }\end{array}$ & $0 \cdot 14 \pm 0 \cdot 02$ & $\begin{array}{l}\text { No change } \\
(\mathrm{p}>0 \cdot 4)\end{array}$ \\
$\begin{array}{l}\text { After 2 weeks of } \\
\text { timolol and } 2 \text { weeks of } \\
\text { timolol and } \\
\text { epinephrine }\end{array}$ & & \\
\hline
\end{tabular}

epinephrine to those patients pretreated with timolol, did not increase outflow facility (Table 4).

\section{Discussion}

An initial additive effect in intraocular pressure reduction is observed when epinephrine is given to patients already on timolol, and vice versa (Fig. 2). However, a statistically significant complete loss of this additive effect occurs when patients are maintained on both drugs for an average of 8 weeks (Tables 1,2).

After treatment with epinephrine alone for 2 weeks a significant increase in facility of outflow was found (Table 3). This is consistent with previous clinical studies. ${ }^{21-26}$ One day after timolol was added to epinephrine no significant change in facility of outflow was found. However, after 2 weeks of combined therapy a significant decrease in facility occurred (Table 3). In the reverse sequence, when epinephrine was added to patients already treated with timolol (Table 4), no increase in facility of outflow was observed. From these data it may be postulated that timolol can block the effect of epinephrine on facility of outflow. This is consistent with Neufeld's experimental finding ${ }^{27}$ that timolol blocks catecholamine-stimulated increase in cyclic adenosine monophosphate (AMP) in the isolated rabbit iris-ciliary body preparation.

Thus, epinephrine probably causes an increase in facility of outflow by a beta receptor mechanism. This finding is of interest because it casts doubt on the validity of the traditional concept of adrenergic receptor sites in the eye. According to this traditional concept, stimulation of alpha receptors in the outflow tract is supposed to increase facility of outflow, whereas stimulation of beta receptors is supposed to affect only the inflow mechanism, resulting in a decrease in aqueous production. ${ }^{28}{ }^{29}$ Although such a concept may offer a logical explanation for the mechanism of action of epinephrine, it does not explain the action of timolol, a drug which selectively blocks beta receptors yet causes a reduction in intraocular pressure.

In addition to our clinical study there are experimental data from studies in primate eyes that contradict this traditional concept. ${ }^{30-33}$ For example, it has been shown that isoproterenol, when injected into the anterior chamber, causes both an increase in facility of outflow ${ }^{33}$ and an increase in the rate of aqueous humour formation. ${ }^{31}$ It has also been observed that alpha-adrenergic stimulation produces no change in facility of outflow. ${ }^{32}$

Based on the clinical data in our study and on experimental data reported by others $\mathrm{s}^{30-33}$ a model of ocular adrenergic receptor sites is proposed which 
Fig. 3 Proposed model of ocular adrenergic receptor sites and effects on aqueous dynamics.
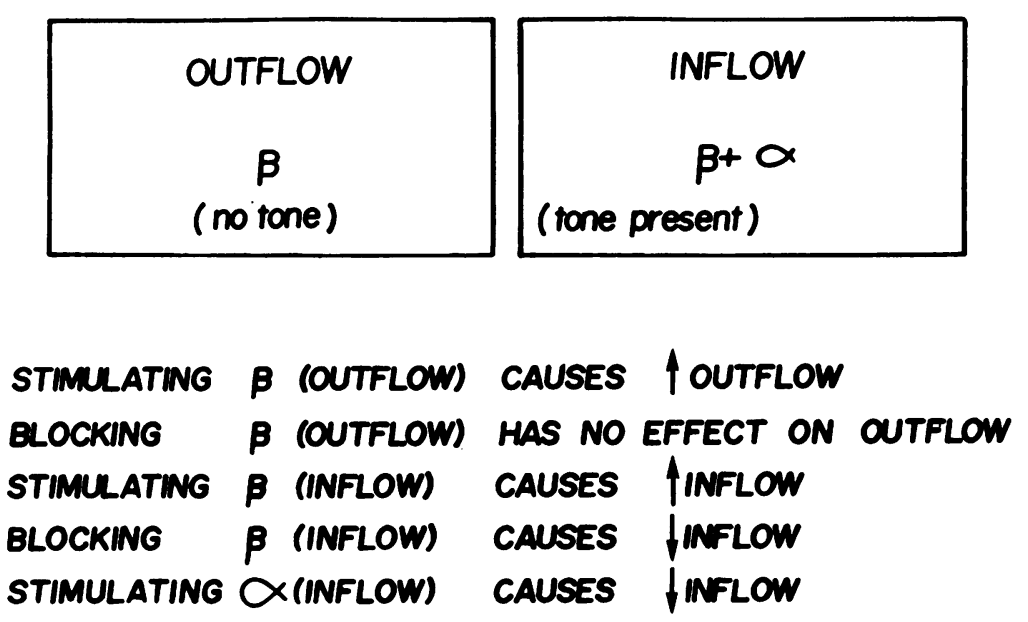

appears to explain, at least partially, the mechanisms of action of timolol and epinephrine in human glaucomatous eyes (Fig. 3). This model is not intended to serve as the 'final mechanism' but rather as a framework for understanding current primate and human glaucoma data and as a basis for further hypothesis and study.

According to this model beta receptors play a role in both the outflow and inflow systems. The beta receptors mediating outflow are possibly located in the trabecular meshwork and stimulating them (e.g., with epinephrine) produces an increase in the facility of aqueous outflow. The assumption is made that these receptors maintain no tone in the outflow system. ${ }^{27}$ Therefore blocking them (e.g., with timolol) has no substantial effect on facility of outflow.

The beta receptors mediating inflow are possibly located in the ciliary processes, and stimulating them (e.g., with epinephrine) produces an increase in aqueous humour formation. The assumption is made that these receptors provide a certain tone to the inflow mechanisms. ${ }^{27}$ Therefore blocking them (e.g., with timolol) causes a decrease in aqueous humour production.

Alpha receptors may also play a role in the inflow mechanism. They are possibly located in the walls of blood vessels supplying the ciliary processes, and stimulating them (e.g., with epinephrine) may cause constriction of these vessels leading to decreased blood flow and consequently decreased aqueous production.

The data from our clinical study are interpreted then as follows. It is postulated that the initial stimulation of beta receptors in the outflow tract by epinephrine alone produced an increased facility of outflow. The addition of timolol blocked this effect of epinephrine on outflow, but produced a reduction of intraocular pressure by reducing the rate of aqueous inflow. This is consistent with previously reported fluorophotometric $^{3435}$ and electro-oculogram ${ }^{36}$ studies which indicate that timolol causes a decrease aqueous production.

Timolol reduces the rate of aqueous production by blocking beta receptors involved with inflow. Stimulating these beta receptors, then, should theoretically cause an increase in aqueous production. Townsend and Brubaker ${ }^{37}$ have recently presented evidence that supports this hypothesis. In a fluorophotometric study of normal human eyes, they found that topical epinephrine did cause an increase in aqueous production (and also an increase in facility of outflow).

When timolol is added to epinephrine therapy we propose that there is a gradual lessening of the additive effect on intraocular pressure because the timolol interferes with the beta agonist effect of epinephrine on outflow (Table 3 ). Timolol has greater affinity for beta receptors than does epinephrine. ${ }^{27} 38$

When epinephrine is added to timolol therapy a temporary reduction in intraocular pressure may be produced (Table 1) by a non-beta (hence, alpha) mechanism (since the timolol would block the epinephrine-beta agonist effect on inflow and outflow). Radius et al. have similarly concluded that the additive effect of epinephrine to timolol is via an alpha mechanism. ${ }^{16}$ This possible alpha effect on inflow apparently diminishes with time (Table 1 ).

The net effect of epinephrine in reducing intraocular pressure in most patients reflects the resultant of beta and alpha effects respectively increasing and reducing inflow, and of the beta effect increasing facility of outflow. in intraocular pressure by reducing the rate of 
The small increase in facility of outflow seen in patients treated with timolol alone for 2 weeks is difficult to explain within the context of this model. Investigators disagree about the effect of timolol on facility of outflow. Some conclude that timolol has no effect on outflow facility, ${ }^{139-42}$ while others ${ }^{784344}$ believe that a small increase in facility occurs after a period of continued use. Perhaps there are differing effects involving $\beta_{1}$ and $\beta_{2}$ receptors that are not addressed in the above model.

It is evident from our data that patients who were treated first with epinephrine for 2 weeks and then supplemented with timolol had significantly lower intraocular pressures for at least 2 weeks than patients in the reverse treatment sequence (Fig. 2). Neufeld's studies of the effects of timolol and epinephrine on the density of beta receptors in ocular tissues is pertinent to this clinical observation. ${ }^{2745}$ Neufeld has shown experimentally that application of epinephrine causes a reduction, and timolol a proliferation, of beta receptors. ${ }^{45}$ It may be postulated that when a patient is treated with epinephrine alone the number of beta receptors is reduced. Then, when timolol is added, relatively few receptors remain for it to act on, and it therefore produces more effective beta blockade and reduction of aqueous production.

From our interpretation of our results we believe there is a reasonable manner in which patients who need both drugs for reduction of intraocular pressure might be more effectively managed. Such patients logically should be treated with epinephrine, first for several weeks and then intermittently with addition of timolol. Such pulsed administration of timolol to patients on epinephrine we expect should provide better overall control of pressure than the continuous administration of both timolol and epinephrine, but the efficacy of this projected regimen is yet to be clinically evaluated.

Lawrence Rand, MD, provided consultation in the design of the study, and Mr Aaron Seidman provided statistical analysis of the data.

This study was supported in part by grants P50EY02518. R01EY01894, and R01EY00002 from the National Eye Institute. and by the American Health Assistance Foundation.

\section{References}

1 Merck Sharp and Dohme Research Laboratories. Preclinical Brochure on Timolol, 1974

2 LeDouarec JC, Vareiller P, Plazonnet B, et al: The effect of timolol, a beta-adrenergic blocking agent, on intraocular pressure in rabbits. Pharmacology 1976; 18: 138-42.

3 Vareiller P. Silverstone D. Plazonnet D. et al. Comparison of the effects of timolol and other adrenergic agents on intraocular pressure in the rabbit. Invest Ophthalmol Visual Sci 1977; 16: 987-96.

4 Katz. IM. Hubbard WA. Getson AJ, et al. Intraocular pressure decrease in normal volunteers following timolol ophthalmic solution. Invest Ophthalmol Visual Sci 1976; 15: 489-92.
5 Zimmerman TJ, Kaufman HE. Timolol: A B-adrenergic blocking agent for the treatment of glaucoma. Arch Ophthalmol 1977; 95: 601-4.

6 Zimmerman TJ, Kaufman HE. Timolol-dose response and duration of action. Arch Ophthalmol 1977; 95: 605-7.

7 Boger WP, Puliafito CA, Steinert RF, et al. Long-term experience with timolol ophthalmic solution in patients with open-angle glaucoma. Ophthalmology 1978; 85: 259-67.

8 Ritch R. Harzett NA. Podos SM. The effect of $1.5 \%$ timolol maleate on intraocular pressure. Acta Ophthalmol (Kbh) 1978; 56: $6-10$.

9 Goethals M, Missotten L. Long-term trial of timolol in different forms of glaucoma. Bull Soc Belge Ophthalmol 1977; 79: 95-101.

10 Kerty E. Hirven I. Glaucoma treatment with timolol. Acta Ophthalmol (Kbh) 1978; 56: 705-14.

11 Vale J, Phillips CI. Effect of dl- and d-propranolol on ocular tension in rabbits and patients. Exp Eye Res 1970; 9: 82-90.

12 Zimmerman TJ, Gillespie JE, Kass MA, et al. Timolol plus maximum-tolerated antiglaucoma therapy. Arch Ophthalmol 1979: 97: 278-9.

13 Sonty S. Schwartz B. The additive effect of timolol on open angle glaucoma patients on maximal medical therapy. Surv Ophthalmol 1979; 23: 381-9.

14 Ashburn FS, Gillespie JE, Kass MA, et al. Timolol plus maximum tolerated antiglaucoma therapy: a one-year follow-up study. Surv Ophthalmol 1979; 23: 389-94.

15 Diamond GR, Werblin TP, Richter R, et al. Extended clinical studies using timolol in patients with ocular hypertension and chronic open angle glaucoma. Glaucoma 1979; 1: 63-8.

16 Radius RL. Diamond GR. Pollack IP. et al. Timolol-a new drug for management of chronic simple glaucoma. Arch Ophthalmol 1978; 96: 1003-8.

17 Katz IM. Beta-blockers and the eve: an overview. Ann Ophthalmol 1978; 10: 847-50.

18 Obstbaum SA, Galin MA, Katz IM. Timolol: effect on intraocular pressure in chronic open-angle glaucoma. Ann Ophthalmol 1978; 10: 1347-51.

19 Nielsen NV. Timolol: Hypotensive effect. used alone and in combination for treatment of increased intraocular pressure. Acta Ophthalmol (Kbh) 1978; 56: 504-9.

20) Bellows AR, Epstein DL, Grant WM. Episcleral venous pressure in eyes with glaucoma and prominent episcleral vessels. Presented at the 1977 Association for Research in Vision and Ophthalmology Meeting. Sarasota. Fla., 25 April 1977. Submitted for publication.

21 Becker B, Petitt TH, Gay AJ. Topical epinephrine therapy on open angle glaucoma. Arch Ophthalmol 1961; 66: 219-25.

22 Ballantine EJ, Garner L. Improvement of the coefficient of outflow in glaucomatous eyes. Arch Ophthalmol 1961; 66: 314-7.

23 Krill AE. Newell FW. Novak M. Early and long-term effects of levo-epinephrine. Am J Ophthalmol 1965; 59: 833-9.

24 Sonntag JR, Brindly GO. Shields MB, et al. Timolol and epinephrine-comparison of efficacy and side effects. Arch Ophthalmol 1979; 97: 273-7.

25 Obstbaum SA. Kolker AE, Phelps CD. Low-dose epinephrine: effect on intraocular pressure. Arch Ophthalmol 1974; 92: 118-20.

26 Richards JSF, Drance SM. The effect of $2 \%$ epinephrine on aqueous humor dynamics in the human eye. Can J Ophthalmol 1967; 2: 259-65.

27 Neufeld AH. Experimental studies on the mechanism of action of timolol. Surv Ophthalmol 1979; 23: 363-75.

28 Richardson KT. Sympathetic physiology and pharmacology. Surv Ophthalmol 1972; 17: 120-31.

29 Havener WH. Ocular Pharmacology. 4th ed. St Louis: Mosby, 1978: 221.

30) Bill A. Early effects of epinephrine on aqueous humor dynamics in vervet monkeys (Cercopithecus ethiops). Exp Eve Res 1969; 8: $35-43$. 
31 Bill A. Effects of norephinephrine, isoproterenol and sympathetic stimulation on aqueous humor dynamics in the vervet monkeys. Exp Eye Res 1970; 10: 31-46.

32 Bill A, Heilmann K. Ocular effects of clonidine in cats and monkeys (Macaca irus). Exp Eye Res 1975; 21: 481-8.

33 Neufeld AH. Influences of cyclic nucleotides on outflow facility in the vervet monkey. Exp Eye Res 1978; 27: 387-97.

34 Coakes RL, Brubaker RF. The mechanism of timolol in lowering intraocular pressure in the normal eyes. Arch Ophthalmol 1978; 96: 2045-8.

35 Yablonski ME, Zimmerman TJ, Waltman SR, et al. A fluorophotometric study of the effect of topical timolol on aqueous humor dynamics. Exp Eye Res 1978; 27: 135-42.

36 Missoten L. Goethals M. Timolol reduces the standing potential of the eye. Ophthalmol Res 1977; 9: 321-6.

37 Townsend DJ, Brubaker RF. Acute effect of epinephrine on aqueous formation in the normal human eye. ARVO, Sarasota, Fla., April 1979.

38 Neufeld AH, Page ED. In vitro determination of the ability of drugs to bind to adrenergic receptors. Invest Ophthalmol Visual Sci 1978; 16: 1069-76.
39 Dausch D. Honegger $H$. The effect of timolol on intraocular pressure: a year-long study. Presentation at the 23rd International Congress of Ophthalmology, Kyoto, Japan. May 1978.

40 Moss AP. Ritch R. Hargett NA, et al. A comparison of the effects of timolol and epinephrine on intraocular pressure. Am J Ophthalmol 1978; 86: 489-95.

41 Zimmerman TJ, Harbin R. Pett M, et al. Timolol and facility of outflow. Invest Ophthalmol Visual Sci 1977; 16: 623-4.

42 Sonntag JR, Brindley GO, Shields MB. Effect of timolol therapy on outflow facility. Invest Ophthalmol Visual Sci 1978; 17:293-6.

43 Boger WP. Steinert R, Puliafito C, et al. A double-masked clinical trial comparing timolol ophthalmic solution and pilocarpine in the therapy of open-angle glaucoma. Am J Ophthalmol 1978; 86: 8-18.

44 Lin LL. Galin MA, Obstbaum SA, et al. Longterm timolol therapy. Surv Ophthalmol 1979; 23: 377-81.

45 Neufeld AH, Zawistowski KA. Page ED. et al. Influences on the density of beta adrenergic receptors in the cornea and iris-ciliary body of the rabbit. Invest Ophthalmol Visual Sci 1978; 17: 1069-75. 